\title{
Avoiding the white elephants: A new approach to infrastructure planning at the 2018 Gold Coast Commonwealth Games?
}

\author{
David Farndon and Paul Burton \\ davidfarndon_df@yahoo.co.uk, p.burton@griffith.edu.au
}

\begin{abstract}
The Gold Coast 2018 Commonwealth Games presented the host city with a number of opportunities to improve its infrastructure and sporting facilities in line with its long-term strategic vision to transition to being a more mature and sustainable Australian city. However, major events such as the Commonwealth Games have a chequered history of bestowing lasting benefits and a positive legacy on the host city. This article examines the ways in which infrastructure planning for the 2018 Games was used to underpin the success experienced by the Gold Coast in harnessing the event to achieve broader city building objectives. It also reflects critically on how major event-led development can be used to support existing strategic city plans.
\end{abstract}

\section{Introduction}

In 2008, Queensland Premier Anna Bligh launched the City of Gold Coast's bid to host the 2018 Commonwealth Games, and one year later announced that the city would have the exclusive right to host any Australian bid. In November 2011, the Gold Coast beat the Sri Lankan city of Hambantota in a vote among members of the international Commonwealth Games Associations for the right to host the Games in 2018. From the outset, there was considerable public debate in Queensland - and indeed beyond - about the merits of hosting a major sporting event such as this and about the balance of costs and benefits.

The public investment required to provide new and upgraded sporting venues, alongside essential public transport improvements, was considered by some to be an unwelcome impost on Gold Coast ratepayers and Queensland taxpayers. Others disputed the claim that staging the Games would create a significant opportunity for the city to develop in a more 'mature' and sustainable manner. At the heart of these debates lay a broader question about the role that major events might play in urban development and growth-management strategies and whether a model for major 
event-led development exists that might be utilised in future infrastructure planning by host cities.

Despite criticisms that major events can lead to development that does not contribute significantly to the everyday functioning of the city (Raco 2004), there was optimism at the outset of the bid for the Games about the benefits that might be harnessed through careful planning. Indeed, in a city whose economy has long been dominated by the property and construction sectors, contributing over one-quarter of the city's gross regional product (City of Gold Coast 2018), it was no surprise that the business community as a whole welcomed the likely economic stimulation provided by building for the Games. Investment in new and refurbished venues was welcomed for keeping much of the local construction sector going during what was otherwise a pronounced economic downturn provoked by the Global Financial Crisis (Kluber 2016).

This article examines the infrastructure planning undertaken by both the state and local government for the 2018 Games to understand the nature and merits of the approach taken to delivering the venues and associated infrastructure. To place this in the broader context of major event development, the article will first highlight the rationale and criticisms of major event-led urban development strategies, describing examples of infrastructure delivery in previous Commonwealth Games held in Brisbane (1982), Melbourne (2006) and Glasgow (2014).

The strategic planning context under which the Gold Coast Games were delivered will then be described in order to explore how the infrastructure planning approach adopted for the Gold Coast Games was shaped in part by an existing long-term vision for the development of the city. This will be followed by an explanation of the development undertaken, including the planned post-Games use of the venues and infrastructure delivered. A detailed discussion of the merits of the Gold Coast's Games infrastructure is then offered, with a critical analysis highlighting a number of successes, as well as some criticisms, that can be attributed to the planning and delivery of the Gold Coast CG and its related infrastructure. Finally, conclusions are drawn to suggest that, while the Gold Coast provided a strategic and often innovative approach to infrastructure planning, it does not represent an entirely new model of city development that could be adopted without modification by other cities.

\section{The case of major event infrastructure investment}

Major events such as the Commonwealth Games and World Trade Fairs, and megaevents such as the Olympics, have become a commonplace feature in urban development strategies, mirroring the popularity and growth of major events as global spectacles. Since the 1980s, cities have been justifying the staging of these major events on the basis that they provide a stimulus for urban regeneration (see Gold and Gold 2017; Smith 2012). Indeed, major events often facilitate the physical restructuring of urban areas and can therefore result in lasting benefits through new facilities and public buildings, a range of wider infrastructural developments, including the upgrading of transportation systems, and beautification projects designed to enhance the city's landscape and environment (Essex and Chalkley 1998, 1999; see also Gold and Gold 2008; Loftman and Nevin 1995). 
Major event-led development strategies have, however, received much criticism. First, the large-scale development that occurs can often be at the expense of existing forms of employment and local attachments to the social or cultural value of places (Raco 2004). Major event-driven development strategies also sometimes struggle to reflect the needs and aspirations of local communities (Raco 2004: 35), with expenditure on new buildings and infrastructure often diverting money away from community facilities and services (Essex and Chalkley, 1998; Lenskyj 2002). There are problems with increasing land values and associated gentrification resulting from major event regeneration (Poynter 2006; Scherer 2011), with local residents sometimes displaced due to the demolition of existing housing to make way for the event infrastructure. For example, the Centre on Human Rights and Evictions estimated that a total of 1.5 million Beijing residents were evicted to make way for the Olympic Games (Gold and Gold 2008: 309). There are also considerable difficulties with embedding large-scale development into the surrounding urban fabric, with new facilities often not providing uses that are in long-term demand or that reflect the social and economic context in which they are built (Gold and Gold 2008; Jones 2001). Indeed, some of the stadia constructed for the Olympic Games in Rio and Beijing have fallen into disrepair as they have struggled to secure viable post-Games uses (The Guardian 2017; Khan 2018).

\section{Commonwealth Games Infrastructure}

The timely delivery of infrastructure and venues associated with the staging of the Games has also been subject to critical scrutiny, with perhaps the most trenchant criticisms being associated with the Delhi 2010 Games. The difficulties experienced by Delhi in delivering the Games included the collapse of a bridge serving the main stadium prior to the Games, the delivery of the A $\$ 300$ million Athletes' Village that was claimed to be 'unfit' for human habitation, and completed facilities with leaky roofs or subsiding floors (Burke 2010). As with other major events, the cost of staging the Games has also been problematic; indeed Durban was stripped of the right to host the 2022 Games after the South African government was unable or unwilling to meet the financial guarantees provided when it secured the successful bid (Gleeson 2017). At the time of writing, it has been reported that the city council of Birmingham, which took over responsibility as host city from Durban, could 'go bankrupt' as a result of Games-related expenditure (Collins and Wheeler 2018), although the city council's leader has denied this in local reports (see Dare 2018).

\section{Contextualising the Gold Coast's approach to infrastructure planning}

The Commonwealth Games has been used by host cities for different purposes and, while improving local infrastructure, sporting and other facilities is a common reason given for staging the Games, there are often other objectives beyond physical development. As was the case in Delhi and Kuala Lumpur, these include political motivations to boost 'national prestige' (see Kakani 2014) and to promote the city on a global stage. Nevertheless, the role of infrastructure is important in delivering any Games, and it is worth briefly highlighting the experiences of two previous Games in Australia - Brisbane (1982) and Melbourne (2006) - and the most 
recent Games in Glasgow in 2014 to contextualise the Gold Coast's infrastructure approach in the light of political and economic organisation and temporal considerations.

Brisbane's Games in 1982 were arguably a pivotal moment in its development into the modern city that we see today, providing the impetus for staging Expo ' 88 and the subsequent regeneration of the South Bank area (Smith 2018). Staging the Games required Brisbane to undertake considerable sports infrastructure development, including the construction of the Queen Elizabeth II (QEII) Stadium and the Chandler Sports Complex. Various existing building were adapted for use, notably Brisbane's City and Festival Halls, while considerable improvements to the urban realm included the creation of the pedestrianised Queen Street Mall in the city centre, the construction of the Albert Park amphitheatre and refurbishment works to landmarks such as the Brisbane Botanic Gardens. Work to improve Brisbane's roads was also undertaken, notably the building of the expressway between the QEII stadium and the city centre (Jolly 2013). One of the successes of Brisbane's 1982 Games was that many of the venues were used for a considerable period postGames.

In 2006, the Melbourne Games provided the city with a range of new and refurbished infrastructure. This included the construction of a new mountain bike course at Lysterfield Park and lawn bowls facilities, and new pitch surfaces at the State Netball Hockey Centre as well as the upgrading of Melbourne's Sports and Aquatic Centre, and the redevelopment of the Melbourne Cricket Ground. A more controversial element was the placement of the Athletes' Village in the inner suburb of Parkville, which attracted criticism for its location and encroachment on the Royal Park (Millar and Ker 2005). Additional 'softer' positive impacts in Melbourne took the form of what has been referred to as 'event themed' regeneration (see Smith and Fox 2007). This notably included Festival 2006, which provided the opportunity to showcase the regenerated Southbank riverside zone, an area previously blighted by its former railway and industrial use, and the existence of contaminated land. The area was transformed in the 1990s and now includes a convention and exhibition centre, a casino and the pre-existing arts centre (Smith 2012). To improve access to the Southbank area, the Victorian Government provided a new footbridge over the Yarra River from the main city centre area, with this crossing opening three days before the start of the Games. Finally, a light and sound 'River Show' was staged each night of the Games, with the city council claiming that that this 'introduced Melbourne to a worldwide television audience and attracted a crowd of around 100,000 spectators on the opening night' (City of Melbourne, in Smith 2012: 117).

Reflecting the 'legacy' theme of London's 2012 Olympic Games, Glasgow saw its Games in 2014 as providing an opportunity to regenerate the East End of the city by 'making effective use of otherwise derelict land and creating employment opportunities for local people' (Glasgow Games 2014: 8). Given that the area was subject to significant deprivation, particularly since the decline in its industrial base, the East End was consciously chosen as the site for the main infrastructure works. Nevertheless, in order to legitimise Games development spending, some commentators were critical that the 'legacy' planning for the area had been premised on 'territorial stigmatisation', whereby the East End had been portrayed as an 'uncivil' place (Gray and Mooney 2011: 19). The development undertaken included the 
construction of the Commonwealth Arena and Sir Chris Hoy Velodrome on land adjacent to Celtic Park, with the Athletes' Village located in close proximity on 35 hectares of brownfield land. After the Games, the Village was converted to provide over 700 homes, with more than half available for rent at affordable levels (Glasgow Games 2014). The Glasgow Green Hockey Centre provided another new venue, while the Tollcross International Swimming Centre was upgraded. Existing venues were also used throughout the city. With regard to associated infrastructure, a series of rail improvements were undertaken, including refurbishment to East End stations (Matheson 2010). However, Matheson (2010) argues that commitments had already been made to make these improvements, along with the building of the arena, prior to the successful bid being announced. This should not necessarily be understood as a pejorative observation, however, as it demonstrates an acceleration of existing plans.

The somewhat distinctive approaches taken by Brisbane (building the city), Melbourne (showcasing the city) and Glasgow (regenerating the city) to the delivery of infrastructure reflect different objectives and circumstances; however, they all demonstrate that their justification for hosting the Games involves a combination of being recognised for delivering an excellent event and making a longer-lasting contribution to the development of their respective cities. Nevertheless, we should remember the significant differences in scale between hosting a major event such as the Commonwealth Games and a mega-event such as the Olympics. This is a matter of 'relativity', considering that other recent major events, such as the Beijing Olympics and the Sochi Winter Olympics, were characterised by large-scale development and expenditure that far exceeded that of these Commonwealth Games examples. This reflects broader political objectives, with China and Russia wishing to enhance their international status (Grix and Kramareva 2017; Grix and Lee 2013), and therefore spending a reported US $\$ 44$ billion and US\$ 51 billion respectively (Gibson 2013; Sudakov 2008) to host the Olympic Games.

These three examples have provided a comparable base and contextual understanding of the nature of development undertaken as part of hosting the Games. We now explore in more detail the Gold Coast Games infrastructure development, initially by providing an explanation of the strategic planning context under which it was undertaken.

\section{Applying the local infrastructure strategy}

When the Gold Coast City Council adopted the 'Our Bold Future' vision statement (Gold Coast City Council 2009), it put in place a strategic and long-term vision that promoted growth while acknowledging the need for it to be managed rather than simply pursued at all costs. The vision statement was mindful of the fact that the very things that made the Gold Coast an attractive place for new residents, entrepreneurs and investors needed careful stewardship. A number of key themes were present in the vision, including enhancing urban design; connecting people and places; ensuring safety and a sense of belonging; supporting a thriving and diverse economy; and protecting the city's environment and distinctive natural assets (Gold Coast City Council, 2009). This strategic vision provided a foundation for the development of the city's bid to host the Games while also aligning with the requirements and expectations of the Commonwealth Games Federation. 


\section{The Gold Coast bid}

The Gold Coast's bid document, The Candidature City File (Gold Coast 2018 Commonwealth Games Bid Company, 2011), emphasised its long-term planning strategy and its alignment with the Games vision. The bid sought to demonstrate the extent and quality of existing infrastructure while also noting proposed improvements. In short, the city declared that it was 'event ready' (Gold Coast 2018 Commonwealth Games Bid Company, 2011), with 'much of the City's Games infrastructure and competition and training venues ... already in place' (Gold Coast 2018 Commonwealth Games Bid Company, 2011). Additionally, the introductory section stated that the Games would deliver 'significant and positive economic, environmental, social and community legacies' (Gold Coast 2018 Commonwealth Games Bid Company, 2011). This combination of readiness and legacy remained a hallmark of the plan for the Games, developed and implemented by a wide-ranging partnership of local, state and federal governments, the delivery organisation GOLDOC, community groups and commercial partners. This new approach to thinking about and planning for the long term marked a new era for the city and enabled it to build a robust case for hosting the Games to the state and federal governments and the Australian Commonwealth Games Association.

Of course, the Games were not planned and delivered by the city council alone; indeed, the bulk of investment in Games infrastructure came from the state government. In keeping with tradition, a Games delivery organisation, the Gold Coast 2018 Commonwealth Games Corporation (GOLDOC), was established on 1 January 2012 under the Commonwealth Games Arrangements Act 2011. The corporation was to undertake and facilitate the organisation, conduct, promotion and commercial and financial management of the Commonwealth Games. Former Queensland Premier, The Hon. Peter Beattie AC, was appointed Chairman in May 2016, succeeding local business leader, Nigel Chamier AM, and former baseball player and sports administrator Mark Peters was appointed chief executive for the duration. In 2015, the state government strengthened the governance arrangements by creating a Tourism and Commonwealth Games Cabinet Committee, chaired by the Minister for Tourism and creating within her department a new Office of Commonwealth Games Delivery.

While these governance arrangements were not immune from criticism, the complex relations between local, state and federal governments, and the important roles played by the semi-autonomous GOLDOC and the Commonwealth Games Federation, were mostly well managed and relatively free from some of the intergovernmental tensions apparent in the governance of previous Games.

Although the City of Gold Coast was only one of many key players in the planning and management of the Games, it occupied a pivotal position in providing a strategic context in which Games infrastructure was planned. From the mid-2000s onwards, the city began preparing a set of long-term strategies to guide its future development - all, to some extent, guided by the overarching principles expressed in its Bold Future strategy. Below, we outline the main features of those strategies of most relevance to the city council's Games bid.

\section{The Gold Coast's strategic planning framework}

In 2013, the city council adopted the Transport Strategy 2031 (Gold Coast City Council 2013), which had the overriding aim of managing the impacts of a rapidly 
growing population and the risk of ever-increasing road traffic congestion. The Transport Strategy set out a long-term program of change to make active and public transport - walking, cycling, buses and rail — more attractive and hence to reduce the number of people reliant on their cars for travel in the city.

This approach shaped the city's preparations for the Games as well, which was recognised as bringing 'a wealth of transport challenges that will require meticulous planning and targeted investment' (Gold Coast City Council 2013: 29). Creating lasting benefits from investment in transport infrastructure was also acknowledged, alongside a desire to limit the need for temporary measures (Gold Coast City Council 2013: 29). During the Games, some temporary restrictions on parking and the introduction of priority lanes on some highways were necessary; however, as documented later, most investment was directed at longer lasting improvements to footpaths and bike paths, to new park-and-ride schemes in strategic locations, and to a new, state-of-the-art traffic-management centre. The most significant investment in transport infrastructure associated with the Games was the construction of the Gold Coast Light Rail. While initial proposals for a light rail system for the city were made in 1996 (see Gold Coast City Council 1996), it was not until 2009 that all three levels of government committed funds to the first stage of the Gold Coast Rapid Transit project. As discussed later, the staging of the Games provided the impetus for the completion of the second stage of the light rail project.

The city's economy has long been built on the twin pillars of tourism and construction: attracting visitors and permanent residents and accommodating them. The publication of the Economic Development Strategy in 2013 (City of Gold Coast 2013a) signalled a new emphasis on diversifying this economic base to allow the city to grow in a more sustained and resilient way. Indeed, the strategy highlighted the desire to diversify the industry and business community, noting the development of 'knowledge-intensive' industries (City of Gold Coast 2013a: 10). The construction of the Athletes' Village within the proposed Gold Coast Health and Knowledge Precinct (GCHKP) - a 'signature project' of the strategy appeared to support and conform to this aspiration. The works for the precinct, located adjacent to Griffith University's Gold Coast campus, were described by the Minister for Innovation and the Commonwealth Games, Kate Jones, as the 'greatest legacy' of the Games, supporting 'thousands of jobs ... and generat[ing] \$2.9 billion for the economy in the next decade' (Queensland Government 2018a).

The Gold Coast Sport Plan 2013-2023 (City of Gold Coast 2013b), also published in 2013, highlights how the city's growing population and increased participation levels for sport require strategic decisions to be made about how best to build upon existing infrastructure. The plan recognises the need to develop a long-term 'sustainable and inclusive sports economy' (City of Gold Coast 2013b: 13). Rather than constructing a swathe of expensive new venues for the 2018 Games with no clear legacy use, the Games provided an opportunity to achieve one of the Sport Plan's goals: the 'maintenance and renewal of sporting facilities' (City of Gold Coast 2013b: 15). This strategic approach has often been missing from major event infrastructure planning, and again demonstrates a clear attempt to ensure that development for the Games was part of a broader, long-term vision for the city.

In summary, when preparing its case to host and then to deliver the Games, the city council and its partners (the state government, and GOLDOC in particular) 
were very conscious of the need not only to deliver an excellent event, but also to contribute to the long-term sustainable growth and development of the city through leaving a significant legacy of infrastructure investment. The city council had already embarked upon an ambitious program of long-term, strategic planning for the city, and hosting the Games provided an excellent opportunity to accelerate and amplify some of the investments envisaged as part of this strategy. The city's more detailed infrastructure plans - especially for transport, economic development and sport - also provided a strategic context for Games investment and at the same time they were shaped by the availability of greater investment associated with the Games.

If the planning of infrastructure investment was handled relatively well, what was delivered in practice and can we as yet draw any conclusions about the likely long-term legacy of this investment?

\section{What was built and its legacy}

The commitment to ensure that investment in Games' infrastructure supported the broader strategic vision for the city is reflected in the nature of the infrastructure delivered through the refurbishment of existing venues and the construction of new facilities.

\section{Venues}

In the light of the problems associated with the construction of many new venues for the Delhi Games and Glasgow's strategy of utilising existing venues - albeit refurbished and extended - only two entirely new buildings were constructed for the Games on the Gold Coast.

The Carrara Sports and Leisure Centre is a new 1500 square metre multipurpose arena used during the Games to host the badminton, powerlifting, weightlifting and wrestling competitions. Completed in 2017, prior to the staging of the Games, the Centre now provides a range of sport and community facilities, with the mixed-use sports courts designed to accommodate basketball, netball, indoor soccer and badminton. This major new facility is located next to the main stadium used during the Games for the opening and closing ceremonies and for track and field events, and now forms part of a growing sports complex in the geographical heart of the city.

Construction of the Coomera Indoor Sports and Leisure Centre began early in 2015 and was complete by August 2016. A multi-purpose community facility with a building footprint of 11,760 square metres, the centre can accommodate exhibitions and concerts as well as a range of elite and community sports, such as netball, volleyball, basketball and gymnastics. During the Games, the $\$ 40$ million centre hosted the gymnastics competition and netball. Research is currently underway to explore how community groups use or would like to use this facility in the future.

Various other venues across the Gold Coast were used, with a number of them being refurbished for the Games. The Carrara Stadium (known also as the Metricon Stadium) hosted the track and field athletics events and the opening and closing ceremonies of the Games. The sports oval and stadiums at Carrara have had a somewhat chequered history since the first was constructed in 1987, serving the needs of various local Rugby League and Australian Rules teams that used them, 
but the stadium is now a major sporting venue for the city and is home to the Gold Coast Suns and to occasional cricket matches.

The lighting facilities at the stadium were upgraded in preparation for the Games, with the refurbishment of tower head frames and associated light fittings undertaken to enhance the highest possible broadcast quality for the Games. Somewhat ironically, the first lights installed at the stadium in 1989, at the behest of disgraced businessman Christopher Skase, were never paid for, despite attempts by the liquidators of Skase's bankrupt business empire to charge them to the City of Gold Coast (Hoyte 2003). An additional 15,000 temporary seats were provided, increasing the overall capacity of the stadium to over 35,000 seats during the Games. As it was not designed to be an athletics stadium, a temporary running track had to be installed at Carrara Stadium for the Games, involving the removal, and subsequent reinstatement, of the ground-level seating at the northern end of the stadium. After the Games, the running track was removed and distributed to local schools and other community facilities, with the stadium's turf pitch reinstated. This approach to making the stadium fit-for-purpose without leaving a legacy of overcapacity was modelled on the experience of Glasgow and contrasts with that of Beijing and Rio de Janeiro, which were left with substantial difficult to use Olympic-standard venues after the conclusion of their Games.

Opened in 1989, the Carrara Indoor Stadium was refurbished in 2017 in preparation for the Games. With a building footprint of 2,100 square metres, the indoor venue contains two multi-use courts and is now open to local community and sporting organisations as well as retaining the capacity to host major indoor events.

With upgrade works completed in early 2017, the Gold Coast Hockey Centre hosted the hockey competition of the Games. The upgrade undertaken provided two all-weather, synthetic pitches and seating for 5,000 spectators. After the Games, the new and upgraded infrastructure at the Gold Coast Hockey Centre continues to support the development of hockey on the Gold Coast and has created opportunities for future training camps and major competitions.

The $\$ 41$ million redevelopment of the Gold Coast Aquatic Centre was accelerated as a result of the Gold Coast's successful bid, with works completed well in advance of the Games. Officially opened in 2014 as a multi-purpose community facility within the Broadland Parklands, the Centre hosted the Pan Pacific Swimming Championships in 2014 and the main pool provided an impressive and distinctive outdoor setting for the swimming and diving competitions during the Games, with temporary seating installed to increase the spectator capacity to 12,000. There was considerable local pressure for the Aquatic Centre to be fully enclosed with a roof, despite the celebrated good weather of the city. This would have added significantly to the cost of the centre and would not have allowed for the installation of the temporary seating that provided a considerable boost to the capacity of the venue without leaving a legacy of substantial over-capacity.

The Broadbeach Bowls Club's \$5.185 million refurbishment was completed in June 2016 in preparation for the Gold Coast Commonwealth Games lawn bowls competition. The refurbishment works included a range of improvements to the venue, including the provision of four international-standard lawn bowls greens and refurbished clubhouse facilities. The venue now caters for a mix of elite and community uses, and is set to host World 2020 Bowls, the world championships of 
lawn bowls. The redevelopment works have established the club as a premier lawn bowls venue in the state as well as the city, providing a world-class competition and training venue for athletes and the wider Gold Coast community.

The mountain bike events for the Gold Coast Commonwealth Games were held in the Nerang National Park, with the start and finish located at the Gold Coast Cycle Centre. The project included a new international competition standard mountain bike trail as well as minor upgrades to the Gold Coast Cycle Centre, which also includes an outdoor velodrome and off-road criterium circuits - all of which can be hired by cycling clubs and casual riders.

One of the more innovative approaches to the venues used saw the Village Roadshow Studios in Oxenford hosting the squash, boxing and table tennis competitions. While the studios were temporarily fitted out to accommodate these sporting events, a notable aspect of this venue was the opportunity it provided to showcase the studio's new 'Super Stage', which had opened in May 2016. This new sound stage, the largest in the southern hemisphere, provides a key piece of infrastructure for attracting large-scale film and television productions. Primarily funded through $\$ 11.5$ million from the Commonwealth Games Infrastructure Fund, the new sound stage is seen as providing an ongoing legacy for the Gold Coast that will deliver long-term economic benefits due to the growing film industry in the city.

Providing the setting for the marathon, triathlon and walking events for the Games, the Broadwater Parklands provides a significant legacy through the provision of new recreational space for the city. Opened in February 2016 at a cost of $£ 10.5$ million, and part (Stage 3) of the ongoing improvement plans for the foreshore, the Broadwater Parklands' works provided an additional 3.5 hectares of land to the north of the Gold Coast Aquatic Centre, new shared community facilities and a home for the Southport Amateur Fishing Club, an environmental education shelter, a four-lane boat ramp, car parking, a shaded playground, and barbecue and picnic facilities. The project was accelerated due to the staging of the Games, with funding provided by the City of Gold Coast and the Gold Coast Waterways.

Finally, the existing Robina Stadium, home to the Gold Coast Titans Rugby League football club, provided the venue for the Rugby Sevens competition, although no refurbishments were required for this facility. In addition to these facilities located in the city, other venues located in Brisbane (Anna Meares Velodrome built specifically for the Games in 2016; Belmont Shooting Centre), Cairns (Convention Centre) and Townsville (Entertainment Centre) were used for preliminary round events.

Although not within the city of Gold Coast itself, the Anna Meares Velodrome is Queensland's first permanent indoor track cycling venue, and serves as the home of Cycling Queensland. Designed by Cox Architecture, it was completed in 2016 at a cost of $\$ 60$ million and has hosted the National Track Championships for the last two years. This project signifies the willingness of the Games organisers and the state government to locate relatively specialised infrastructure in the most sensible location for a major state facility, while retaining its overall commitment to focus the Games on the Gold Coast. 


\section{Athletes' Village}

One of the largest facilities constructed for the Games was the Athletes' Village, located adjacent to Griffith University on the site of the old Gold Coast Parklands, which previously had been home to dog racing, trotting, the annual Gold Coast Show and various music festivals. The Athletes' Village housed over 6,500 athletes and team officials, and was built by the development company Grocon; it is perhaps the most significant legacy project resulting from the Games. Nevertheless, it was highly regarded by its residents during the Games, for the quality of the accommodation, its setting and its accessibility.

Located within the much broader GCHKP, which covers over 29 hectares, the Village - now known as the Smith Collective — provides a mixed-use residential community of 1,170 apartments and 82 townhouses. These are set within seven acres of landscaped open space with a host of shops and other communal facilities, and are adjacent to the emerging health and knowledge research and development facilities as well as two hospitals and a major university. The Smith Collective aims to become a community for long-term renters and provides a new approach to tenancy management, allowing pets, the easy renewal and transfer of tenancy agreements and a degree of latitude in decorating apartments that are by no means typical of the Australian private rental sector.

\section{Associated infrastructure}

A number of projects were undertaken to improve transport infrastructure and the urban realm within the city and while it is not possible to detail all the works undertaken, the more prominent projects are highlighted below.

\section{Transport infrastructure}

A number of transport infrastructure works were carried out in preparation for hosting the Games. While the initial decision to invest in a light rail system for the Gold Coast was made in the context of deciding whether or not to bid to host the Games (it was always difficult to imagine a plausible bid that relied on the preexisting bus network as the main form of public transport in the city), the decision to bring forward a \$420 million investment in Stage Two of the G-link (as the Light Rail system became known) so that it was operational in time for the Games was even more contentious. Although some prominent local politicians saw no need to bring forward the construction of Stage Two - which would extend the network and connect it with the existing 'heavy rail' service to Brisbane - in time for the Games, it was in fact approved and operational in early 2018. This extension proved especially popular, as it offered good access to the Games for a substantial population in the catchment of the South East Queensland rail network and provided interstate and international visitors arriving at Brisbane International Airport with a direct public transport link to the city. Park and ride facilities at several light rail stations were also enhanced to cope with extra patronage during the Games, and these now offer another valuable legacy.

A number of road infrastructure projects were also accelerated in order to support the transport network during the Games and to provide legacy benefits. Funded by the state government and the City of Gold Coast, the $\$ 166.9$ million improvements included upgrades to major roads and intersections within the city, the provision of dedicated bicycle lanes and improved signalling. 
Of particular importance was investment in the active transport network of the city and associated campaigns of encouragement to cycle and walk to venues, at least for the 'last mile'. Again, this investment was consistent with the city's Transport Strategy 2031, which contains its Active Transport Plan (Gold Coast City Council 2013). This strategy was complemented by the City's Behaviour Change Plan, which encourages sustainable travel by residents and visitors, with the Games providing an opportunity to promote a sustainable transport legacy for the city. As part of this initiative, alongside ensuring that congestion was avoided during Games time, the city invested $\$ 7.6$ million into providing advice and support prior to, during and after the Games. In terms of the staging of the Games, this advice sought to reduce travel during Games time, and encouraged commuters to avoid peak hours and alter their routes to avoid the busiest areas. Additionally, walking, cycling, car-pooling and public transport were promoted as ways to minimise impact on the transport network.

While this approach ensured that the transport system ran smoothly, including encouraging a significant number of visitors by rail from Brisbane, it may have been too successful in that it led to many local residents leaving the city and some regular visitors staying away during the Games. Indeed, little congestion was reported, with many of the main roads and the M1 experiencing substantial reductions in use. Nevertheless, unfounded fears over congestion from staging a large-scale sporting event are not uncommon and the associated tourism benefits from staging major events are commonly over-emphasised. The same concerns over the capacity of the transport network were raised for the London 2012 Olympics, with the city actually experiencing a reduction in the number of tourists visiting the city during the Olympic period - an outcome thought to be associated with an exaggeration of the potential for congestion on transport and at the city's attractions. A balance between managing congestion, encouraging tourism and enabling the everyday functioning of the city is a challenge that will need to be given further consideration in future transport strategies for Games host cities.

\section{Improvements to the urban realm}

One of the most visible, if not small scale, projects undertaken for the Games was the improvement works to the urban realm in some of the city's precincts. The City Presentation program was designed to improve the appearance and safety of these precincts and provide a lasting benefit for Gold Coast residents. Included in the program were works to the Broadbeach Mall, where $\$ 1.2$ million was spent on ground resurfacing, planting, and street furniture improvements and \$1.7 million was spent on revitalising the Southport Mall, including new road surfacing, pavements, street furniture and bicycle racks. These were especially significant as they improved the quality of the pedestrian connection between the light rail station in Southport and the Aquatic Centre in the Broadwater Parklands. These works were also designed to consolidate Southport's claim to be the city's central business district.

\section{Discussion}

The merits of staging a major event such as a Commonwealth Games have been subject to much debate in recent times. With regard to infrastructure, this debate has raised concerns over the cost of constructing new venues to host the sporting events 
and the difficulties in securing and maintaining post-event uses for each venue. The Gold Coast Games succeeded in avoiding many of these problems as only two new venues were constructed, with the majority of the sporting competitions held existing venues and facilities - albeit upgraded ones. This approach relied on a creative approach to venue delivery with, for example, the innovative temporary installation of an athletes' running track at Carrara Stadium, the use of temporary seating at the outdoor Aquatics Centre, and the staging of sporting events at the Village Roadshow Studios, which enabled the promotion of the studio's new sound stage.

The Games were not inexpensive, however, with the Queensland State government spending approximately A $\$ 2$ billion (US $\$ 1.5$ billion) in delivering the event through a combination of new and accelerated investment. Whilst this exceeds the $£ 543$ million (US\$751 million) cost of hosting the 2014 Games in Glasgow, it is considerably less than the US\$4.1 billion cost of the 2010 Delhi Games (Miller 2018). As noted earlier, the contrasting spends on major events are often largely the result of differing economic and political contexts and goals alongside the existing infrastructure base. Nevertheless, the fact that the Gold Coast Commonwealth Games were delivered without excessive expenditure and did not leave any 'white elephant' venues or facilities is a significant achievement - although not unexpected, given the careful planning undertaken to ensure that the event fitted into a longterm vision for the city.

This vision is one that, as noted earlier, sought to align the Games with existing infrastructure plans for the city to meet its growing population and the increase in sporting participation among its residents. This is demonstrated by Queensland Government reports suggesting that all Gold Coast Games venues are fully booked for the rest of 2018 (Queensland Government 2018b). Additionally, it is noted that a number of the events proposed within the venues over the coming year, such as the Queensland Gymnastics Championships and the Australian Squash Club Championships, are of national significance. This success in sustaining post-Games usage supports the city's desire to be recognised as a plausible destination for major sporting events.

The putative benefits of hosting the Games included more than additional or accelerated investment in infrastructure. Delivering a successful Games would demonstrate to others that the city was capable of successfully hosting major sporting events, and global television and other media coverage would bring the city to the attention of people across the world, who might then consider visiting the Gold Coast as tourists, enrolling as tertiary students, relocating as residents or investing as businesses. It is still too early to tell whether these have come to pass, and research in this field faces the well-known, but nevertheless difficult to calibrate, problem of establishing a counterfactual - in other words, what would have been the future trajectory of visitor numbers, student enrolments or new investment without any 'Games effect'? Similarly, there are not as yet any robust and reliable measures of changes (positive or negative) to the city's global reputation or standing.

Nevertheless, Gold Coast Deputy Mayor Donna Gates suggested that the Games injected $\$ 2$ billion into the local economy (Larkins, 2018), while other reports have claimed that the city would achieve an A $\$ 870$ million 'economic injection' from visitors in the lead-up to and during the Commonwealth Games, with a further 
$\mathrm{A} \$ 488$ million from direct foreign investment on top of increased tourism revenue resulting from the global exposure generated by the Games (Peel 2018).

With regard to any detrimental impacts, there was criticism during the Games that warnings from various quarters about the prospective traffic congestion in and around the Gold Coast area had driven locals away and dissuaded regular visitors from staying in the city. Indeed, some local businesses were highly critical of what was seen as the congestion 'scare campaign' and its impact on trade (Stevenson and Kinsella 2018). While one might intuitively expect a significant number of visitors to attend such a major event, it is quite a common occurrence that regular visitors, as well as locals, are often deterred by the prospect of congestion or overcrowding, thereby reducing the number of patrons for local business. This matter is particularly pertinent for an already established tourist destination such as the Gold Coast, and tends to support similar claims made during the London 2012 Olympics that traditional tourist areas of the city were 'ghost towns' (Woodman, 2012). On the other hand, criticism would probably have been even more vociferous if there had been extensive congestion (over and above normal levels) within the city and between the Gold Coast and Brisbane, along with a perception that this had not been anticipated and planned for. A concerted campaign, 'Get Set for the Games', which was supported by local and state governments, business and community groups, provided advice and support to businesses and individuals to not only mitigate potential congestion problems, but also to benefit commercially from more and different visitors.

Despite this issue, and criticisms regarding attendees experiencing extended twohour waiting times for buses outside the Carrara Stadium following the opening ceremony (Siganto and Stevenson 2018), the organisation of transport infrastructure during the Games should be considered a success. Indeed, the light rail system was reported to have had almost 1.1 million passengers during the event, equating to almost four times the usual patronage rate (Keolis Downer 2018). While 'soft benefits', such as increased civic pride among residents of the city, should be considered when assessing the merits of staging the Games, it is obviously the physical infrastructure that provides the most prominent and tangible legacy for the Gold Coast. The extension to the light rail, road improvements, active transport linkages and urban realm improvements are all examples of investment in public infrastructure that was accelerated by the Games.

\section{Conclusions}

The Gold Coast has a unique combination of attributes that provided a solid foundation for delivering a successful Games and leaving a lasting legacy of public infrastructure. Its experience as a major tourist destination and successful host of increasingly significant sporting events; its climate and proximity to spectacular natural environments - especially the beaches and hinterland mountains; and its existing commitment to long-term, strategic planning for the city's future growth came together to create this platform for success. The city council also seized the opportunity of hosting the Games to advance its ambition to allow the Gold Coast to grow into a more mature city (Leach 2018). As Smith (2018) notes, the Gold Coast authorities had wanted to show the world that they had 'matured from simply a tourist resort to fully fledged city'. Like Brisbane's efforts in the 1980s to 
harness its Games as an opportunity to transform that place from 'a big country town' into a 'new world city', the Games came at an ideal time for the Gold Coast to mark its transition from an adolescent to a more 'grown-up' city (Burton 2009). Unlike Brisbane, Melbourne and Glasgow, though, the Gold Coast did not set out to use the Games to stimulate the regeneration of a significant part of the city - the South Bank waterfront, Docklands or the East End respectively. Furthermore, apart from the required relocation of the Gold Coast Showgrounds to make way for the Athletes' Village at Parklands, there was no displacement of existing uses or communities, as is often the case in major event development. Indeed, the Gold Coast Games largely avoided significant public disapproval over its venue and infrastructure planning, unlike the political problems associated with Melbourne's Athletes' Village and criticism of the treatment of Glasgow's East End residents as part of that city's Games planning.

In conclusion, the decision of the city council to bid to host the 2018 Games was entirely consistent with its increasing commitment to long-term planning to manage the growth of the city and to enable it to transform its popular image as a 'sunny place for shady people' (Jones 1986) into a more mature and sophisticated place. In securing the support of the state government and the Australian Commonwealth Games Association for the right to bid, the city council was able to capitalise on a unique combination of factors, including its track record as a tourist destination, its natural assets and its planning capacity and foresight. It succeeded in rebuffing attempts to brand the Games a Queensland event - even if some preliminary and specialist events were held elsewhere - and was able to capitalise on the track record and connections of its mayor (until 2012), former athlete Ron Clarke, especially in the late stages of voting among the Commonwealth associations. While some locals bemoaned the expenditure of considerable sums of public money (albeit mostly from state and federal coffers) on the event, the tangible legacy of new and improved sporting infrastructure assuaged many of these concerns. It can be argued that one of the most significant pieces of city-building infrastructure investment the light rail - would not have happened at all, or would certainly not have progressed as quickly, had it not been for the Games. While they are beyond the scope of this article, many of the initiatives associated with the Games, such as the stimulation of local volunteering, a greater appreciation of local Aboriginal culture and a growing awareness of the economic potential of major event tourism, have helped to build an awareness within and beyond the city that it has become a more economically, socially and culturally diverse place.

Does the Gold Coast experience provide a template for future host cities, or was it indeed a unique experience? In some respects, the operational capacity and experience associated with hosting a successful Games are now almost taken for granted, and it is other elements that are becoming more important in securing hosting rights. The willingness and capacity to leave a positive legacy of event infrastructure, whether it be venues and facilities or organisational capability; a contribution to building a more sustainable city; and the incorporation of a wider program of cultural events that celebrate diversity, multiculturalism and (where relevant) Indigenous heritage are more important now than at any time in the history of the Games. The Gold Coast was able to deliver on each of these objectives, not least by learning from the experience of previous hosts of the Commonwealth Games and other major sporting events. A further part of the positive legacy of the Gold Coast 
Games stems from the involvement of the city's major university, Griffith University, and the establishment of a Commonwealth Sport University Network to support research on all aspects of the Games. This will enable ongoing, comparative research on, inter alia, the development of more robust measures of legacy, including the longterm impacts of investment in city building infrastructure. This should help to make more robust the process of selecting future host cities and evaluating their plans and performance, and thereby enhancing the prospects of staging a sustainable Commonwealth Games.

\section{Conflict of interests}

Paul Burton receives funding from the City of Gold Coast as part of a longstanding research collaboration around planning and growth management, but otherwise the author(s) have no potential conflicts of interest with respect to the research, authorship, and/or publication of this article.

\section{Acknowledgements}

We would like to thank two anonymous referees for their helpful comments on earlier versions of this article. The views and opinions expressed in this article are those of the authors and do not necessarily reflect those of the organisations with which the authors are affiliated.

\section{References}

Burke, J. 2010. 'Does this look ready to you? Chaos in run-up to Commonwealth Games', The Guardian, 22 September. https://www.theguardian.com/sport/2010/ sep/21/commonwealth-games-collapse-bridge-delhi.

Burton, P. 2009. 'Growing pains: Adolescent urbanism on the Gold Coast'. Paper presented to State of Australian Cities, University of Western Australia, Perth, 25-27 November.

City of Gold Coast 2013a. Economic Development Strategy 2013-2023. Gold Coast: City of Gold Coast.

City of Gold Coast 2013b. Gold Coast Sport Plan 2013-2023. Gold Coast: City of Gold Coast.

City of Gold Coast 2018. 'Economic profile'. https://economy.id.com.au/gold-coast.

Collins, D. and Wheeler, C. 2018. 'Commonwealth Games 2022 could bankrupt Birmingham', The Times, 16 September. https://www.thetimes.co.uk/article/ commonwealth-games-2022-could-bankrupt-birmingham-920rlg32z.

Dare, T. 2018. 'Commonwealth Games “will not bankrupt” Birmingham, despite claims’. Birmingham Post, 8 October. https://www.birminghampost.co.uk/news/ regional-affairs/commonwealth-games-will-not-bankrupt-15237871.

Essex, S. and Chalkley, B. 1998. 'Olympic Games: Catalyst of urban change'. Leisure Studies 17(3): 187-206.

Essex, S. and Chalkley, B. 1999. 'Urban development through hosting international events: A history of the Olympic Games'. Planning Perspectives 14(4): 369-94. 
Gibson, O. 2013. 'Sochi 2014: The costliest Olympics yet but where has all the money gone?' The Guardian, 9 October. Retrieved from https://www.theguardian.com/ sport/blog/2013/oct/09/sochi-2014-olympics-money-corruption.

Glasgow Games 2014. 'Commonwealth Games Village, Glasgow 2014'. Retrieved from http://www.glasgow2014.com/About+Our+Games/Village+and+Venues/The +Commonwealth+Games+Village.html.

Gleeson, M. 2017. 'Durban loses right to host 2022 Commonwealth Games'. Reuters, 14 March. https://www.reuters.com/article/us-games-commonwealth-durban/durbanloses-right-to-host-2022-commonwealth-games-idUSKBN16K1UN.

Gold, J. R. and Gold, M. M. 2008. 'Olympic cities: Regeneration, city rebranding and changing urban agendas. Geography Compass 2(1): 300-18.

Gold, J. R. and Gold, M. M. 2011. 'The enduring enterprise: The Summer Olympics, 1896-2012', In J.R. Gold, and M.M. Gold (eds.), Olympic cities, planning, and the world's Games, 1896-2020, 3rd ed., Abingdon: Routledge, pp. 21-63.

Gold Coast City Council 1996. Gold Coast City Council Transport Plan. Gold Coast: Gold Coast City Council.

Gold Coast City Council 2009. Our vision for the future of the Gold Coast: Gold Coast City Council has endorsed the following Bold Future elements for our city. Gold Coast: Gold Coast City Council.

Gold Coast City Council 2013. Gold Coast City Transport Strategy 2031. Gold Coast: Gold Coast City Council.

Gold Coast 2018 Commonwealth Games Bid Company (2011) Gold Coast City Candidate City File, Gold Coast: Gold Coast 2018 Commonwealth Games Bid Company.

Gray, N. and Mooney, G. 2011. 'Glasgow's new urban frontier: "Civilising” the population of "Glasgow East”'. City 15(1): 4-24.

Grix, J. and Kramareva, N. 2017. 'The Sochi Winter Olympics and Russia's unique soft power strategy', Sport in Society 20(4): 461-75.

Grix, J. and Lee, D. 2013. 'Soft power, sports major-events and emerging states: The lure of the politics of attraction. Global Society 27(4): 521-36.

The Guardian 2017. 'Rio Olympic venues already falling into a state of disrepair'. The Guardian, 10 February. https://www.theguardian.com/sport/2017/feb/10/rioolympic-venues-already-falling-into-a-state-of-disrepair.

Hoyte, C. 2003. 'An Australian mirage'. PhD thesis, Griffith University.

Jolly, R. 2013. Commonwealth Games: Friendly rivalry. Canberra: Parliament of Australia.

Jones, C. 2001. 'A Level Playing Field? Sports Stadium Infrastructure and Urban Development in the United Kingdom'. Environment and Planning A: Economy and Space 33(5): 845-861.

Jones, M. 1986. A sunny place for shady people: The real Gold Coast story. Sydney: Allen \& Unwin.

Kakani, C. 2014. 'India in focus: "India's Commonwealth Games: A national disgrace”'. The Objective Standard, 30 January. https://www.theobjectivestandard.com/issues/ 2010-winter/india.

Keolis, D 2018. 'Gold Coast light rail: A star performer of the Commonwealth Games transport plan’. 26 April. https://www.keolisdowner.com.au/glink-commonwealthgames. 
Khan, S. 2018. 'Ten years after Beijing's triumphant Olympic Games, many venues lie abandoned, rotting and forgotten'. The Independent, 7 August. https:// www.independent.co.uk/news/world/asia/beijing-olympics-venues-2008-derelictathletics-swimming-a8479771.html.

Kluber, A. 2016. 'Why the Gold Coast is enjoying a return of investors and tourists'. Financial Review, 22 March. https://www.afr.com/brand/afr-magazine/why-thegold-coast-is-enjoying-a-return-of-investors-and-tourists-20160214-gmu1gr.

Larkins, D. 2018. 'Commonwealth Games: Looking back at Gold Coast 2018 as organising committee calls it a day'. ABC News, 29 August. https:/www.abc.net.au/ news/2018-08-29/gold-coast-2018-hailed-one-of-best-as-organisers-call-it-a-day/ 10179072.

Leach, A. 2018. Gold Coast: City and architecture. London: Lund Humphries.

Lenskyj, H. 2002 The Best Olympics Ever? Social Impacts of Sydney 2000. New York: State University of New York Press.

Loftman, P. and Nevin, B. 1995. 'Prestige projects and urban regeneration in the 1980s and 1990s: A review of benefits and limitations'. Planning Practice \& Research 10(3/ 4): 299-315.

Matheson, C. 2010. 'Legacy planning, regeneration and events: The Glasgow 2014 Commonwealth Games'. Local Economy 25(1): 10-23.

Millar, R. and Ker, P. 2005 'Vow on Games village broken'. The Age, 5 February. https:/www.theage.com.au/news/National/Vow-on-Games-village-broken/2005/02/ 04/1107476803807.html.

Miller, A. 2018. '2018 Commonwealth Games takes schedule and budget golds'. Acca Think Ahead, 1 April. https://www.accaglobal.com/gb/en/member/member/ accounting-business/2018/04/insights/commonwealth-games.html.

Peel, C. 2018 'Gold Coast event puts a shine on city coffers'. The Australian, 16 April. https:/www.theaustralian.com.au/sport/2018-commonwealth-games/gold-coast-eventputs-a-shine-on-city-coffers/news-story/b572964fb137d8d689cd1575ca0426fb? $\mathrm{nk}=\mathrm{bde} 694 \mathrm{fc} 2799425042 \mathrm{c} 0 \mathrm{~b} 2 \mathrm{~d} 4 \mathrm{ee} 567951-1540708949$.

Poynter, G. 2006. From Beijing to Bow Bells: Measuring the Olympics effect. Working Papers in Urban Studies. London: London East Research Institute/University of East London.

Queensland Government 2018a. 'Games legacy to make Coast a global hub for innovation'. Media statement, Queensland Government, 11 April. Retrieved from http://statements.qld.gov.au/Statement/2018/4/11/games-legacy-to-make-coast-aglobal-hub-for-innovation.

Queensland Government 2018b 'Coast Commonwealth Games venues booked out for 2018'. Queensland Government, 31 May. http://statements.qld.gov.au/Statement/ 2018/5/31/coast-commonwealth-games-venues-booked-out-for-2018.

Raco, M. 2004. 'Whose Gold Rush? The Social Legacy of a London Olympics', In VigorA., MeanM., and TimsC. (eds.), After the Gold Rush: A Sustainable Olympics for London, London: IPPR/Demos.

Scherer, J. 2011. 'Olympic villages and large-scale urban development: Crises of capitalism, deficits of democracy?' Sociology 45(5): 782-97.

Siganto, T. and Stevenson, A. 2018. 'Commonwealth Games commuters demand money back after two-hour wait for buses’. ABC News, 5 April. https:/www.abc.net.au/news/ 2018-04-05/commonwealth-games-commuters-two-hour-wait-for-buses/9620934. 
Smith, A. 2012. Events and urban regeneration: The strategic use of events to revitalise cities. Abingdon: Routledge.

Smith, A. 2018. 'How the Gold Coast Games transformed a resort region into a city'. The Conversation, 13 April. https:/theconversation.com/how-the-gold-coast-gamestransformed-a-resort-region-into-a-city-94877.

Smith, A. and Fox, T. 2007. 'From "event-led" to "event-themed” regeneration: The 2002 Commonwealth Games Legacy Programme'. Urban Studies, 44 (5/6): 1125-43.

Stevenson, A. and Kinsella, E. 2018. 'Traffic "scare campaign" has driven locals and visitors away from Gold Coast, traders say'. ABC News, 9 April. https:// www.abc.net.au/news/2018-04-09/traffic-scaremongering-drives-tourists-away-fromgold-coast/9632972.

Sudakov, D. 2008. 'Beijing Olympics to cost China 44 billion dollars'. Pravda.ru, 6 August. http://www.pravdareport.com/sports/games/06-08-2008/106003-beijing_olympics-0.

Woodman, P. 2012. 'London tourism struggles during Olympics'. The Independent, 31 July. https://www.independent.co.uk/news/uk/home-news/london-tourism-strugglesduring-olympics-7994159.html. 